\title{
From Berlin-Dahlem to the Fronts of World War I: The Role of Fritz Haber and His Kaiser Wilhelm Institute in German Chemical Warfare
}

\author{
Bretislav Friedrich and Jeremiah James
}

\begin{abstract}
There is little doubt that Fritz Haber (1868-1934) was the driving force behind the centrally directed development of chemical warfare in Germany, whose use during World War I violated international law and elicited both immediate and enduring moral criticism. The chlorine cloud attack at Ypres on 22 April 1915 amounted to the first use of a weapon of mass destruction and as such marks a turning point in world history. Following the "success" at Ypres, Haber, eager to employ science in resolving the greatest strategic challenge of the war-the stalemate of trench warfare-promptly transformed his Kaiser Wilhelm Institute for Physical Chemistry and Electrochemistry in Berlin-Dahlem into a center for the development of chemical weapons and of protective measures against them. This article traces in some detail the path from Berlin-Dahlem to the fronts of World War I, lays out the indispensible role of Fritz Haber in German chemical warfare and provides a summary of his views on chemical weapons, which he never renounced.
\end{abstract}

\section{The Run-up to Ypres}

The lingering idea of using chemicals to incapacitate enemy troops had been rekindled by the belligerents in World War I once trench warfare produced a strategic stalemate on the war's Western front. On the German side, it was likely Max Bauer of the Supreme Army Command (Oberste Heeresleitung, OHL), see Fig. 1, who proposed to OHL's Chief, Erich von Falkenhayn, already in September 1914, to consider the use of chemical weapons in trench combat (Haber 1924, 85). In response to Bauer's proposal-and in the face of the shock of the Battle of the Marne ${ }^{1}$ - von Falkenhayn promptly established a committee comprised of scien-

\footnotetext{
${ }^{1}$ Ending in Allied victory, this week-long battle (September 5-12, 1914) set the stage for the immovable trench warfare of the next four years of WWI.

B. Friedrich $(\bowtie) \cdot$ J. James

Fritz Haber Institute of the Max Planck Society, Faradayweg 4-6, 14195 Berlin, Germany

e-mail: brich@fhi-berlin.mpg.de

(C) The Author(s) 2017

B. Friedrich et al. (eds.), One Hundred Years of Chemical Warfare: Research,

Deployment, Consequences, DOI 10.1007/978-3-319-51664-6_3
} 
tists, industrialists and military officers, to assess the suitability and availability of various chemicals as weapons (Szöllösi-Janze 1998, 321-332 and references cited therein). Among the committee members was Fritz Haber's scientific rival, the physical chemist Walther Nernst, as well as the chemist and industrialist Carl Duisberg - but not Haber himself. The brainchild of the fledgling chemical warfare committee was the ineffective sneezing powder (Ni-Stoff) that was used amid the hostilities at Neuve-Chapelle already during the same month that the committee was formed. In response to the Ni-Stoff fiasco, Gerhard Tappen of the OHL, see Fig. 1, turned for help to his brother Hans Tappen, a chemist trained by Emil Fischer. Hans Tappen proposed to fill artillery shells with the lachrymator xylyl bromide, hence dubbed T-Stoff, that was first tested in January 1915. It was promptly used at the Eastern front, near Lodz, in cold weather with little or no effect due to its low vapor pressure at low ambient temperatures. At that point, von Falkenhayn decided to take his gloves off, abandon the "smelly stuff" and make use of lethal chemicals (substances that "incapacitate permanently," as he put it) in order to break the stalemate of trench warfare (Martinetz 1996, 18). To this end, Fritz Haber, who had meanwhile become, along with Emil Fischer, a member of Falkenhayn's chemical warfare committee and was privy to the failure of T-Stoff, proposed the use of chlorine as a chemical weapon. Heavier than air and thus suitable for striking enemy troops inside their trenches, chlorine held the promise of not only killing enemy combatants but also incapacitating their "conventional" weapons by corrosion. Although Haber would have preferred delivery via a barrage of artillery shells, he bowed to the need of the military to save ammunition and proposed to discharge the lethal gas from a great number of cylinders in the form of a cloud.

An attempt to test chlorine as a chemical weapon at the proving ground in Wahn near Köln in January 1915 was aborted due to the dangerousness of the gas and a decision was made by the OHL to test a chlorine cloud directly in battle on the Western front. Although viewed with skepticism and mistrust by most of the military, including von Falkenhayn himself, the idea of deploying a chlorine cloud found support from generals Berthold von Deimling and Emil Ilse, who were in charge of German operations in Flanders and who set their eye on the Ypres Salient, which, according to the Schliefen Plan, lay on the German Army's route into France. Von Deimling: "War is self-defense that knows no rules" (Deimling 1930, 201).

Much of the high-ranking German military took a more scrupulous-or chivalrous - approach to chemical weapons and at first openly detested them, thereby furnishing a curious substitute for the adherence to the spirit, if not letter, of the Hague conventions from 1899 and 1907 that limited the use of poisonous substances in warfare. 


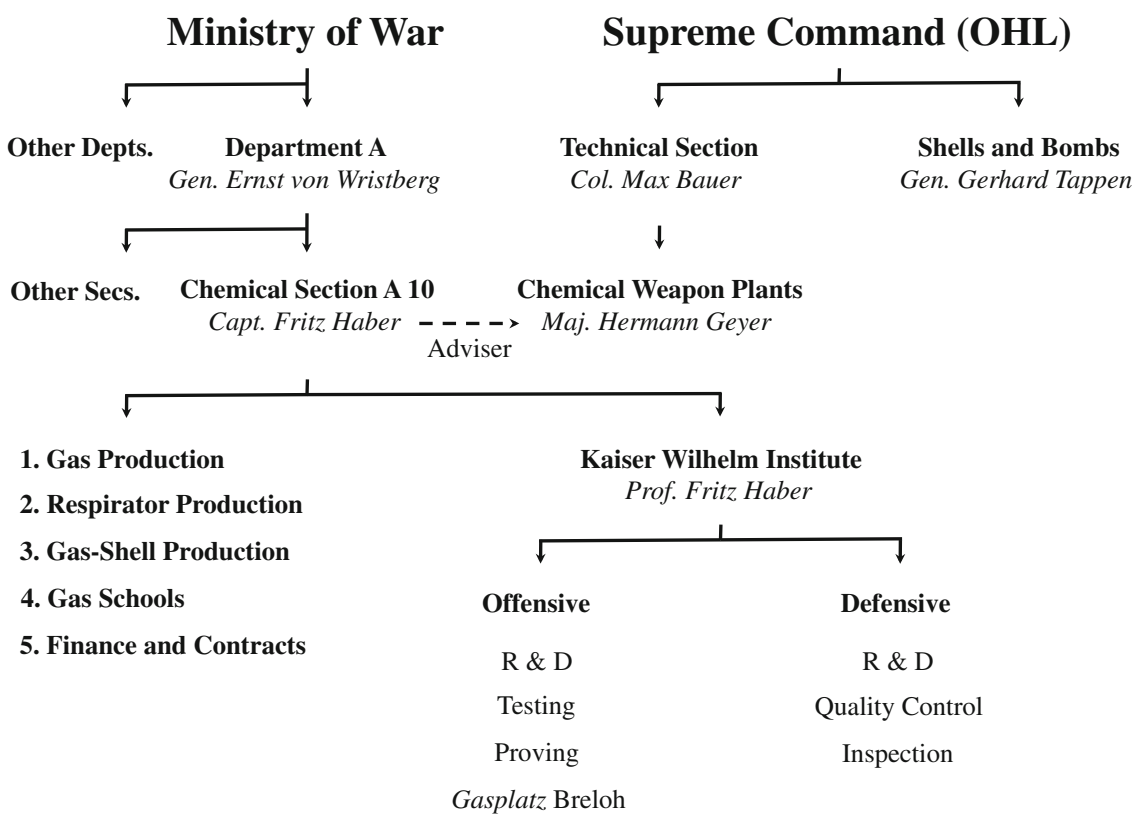

Fig. 1 Organization chart of the German chemical warfare from the end of 1916 on. After Haber 1986, 140

\section{Ypres, 22 April, 1915, 1700 GMT}

The commander of the gas units was Col. Peterson, with Fritz Haber co-opted as a member of his four-member staff. ${ }^{2}$ The gas-warfare personnel, comprised of volunteers, was trained mainly in handling of gas cylinders, their transport, and protection. The steel cylinders were to be dug-in upright behind the battlements of the trenches and shielded with sand bags. Only the lead pipes were to peep out from the parapets, see Fig. 2. The training took place in Wahn during January 1915, but soon the chemical units, posing as "disinfection crews," started moving to their positions on the Western front, reaching Ypres in February 1915. In the meantime, on Haber's urging, many of the officer positions of the gas units were staffed with scientists - including meteorologists. These units would later become a part of the army corps of engineers (Pionierregiment or -bataillon). The movement of the chemical units and of their equipment to the front was accompanied by many mishaps, not least of them a serious injury suffered by Fritz Haber and Max Bauer on April 2 when they were caught in the midst of a small chlorine cloud released for testing purposes (Haber 1924, 88).

\footnotetext{
${ }^{2}$ The other members were adjutant Otto Lummitsch and Col. Ludwig Hermann (Szöllösi-Janze 1998, 327).
} 


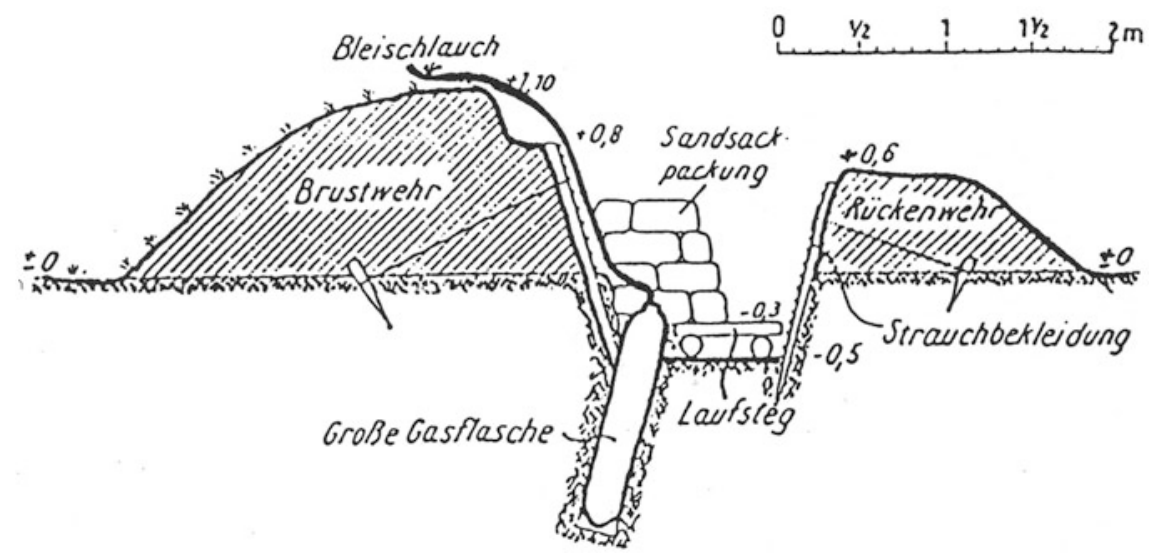

Fig. 2 Cross-sectional schematic view of a trench with a chlorine cylinder in position. After Martinetz 1996, VII

The first chlorine cloud attack on enemy positions (French and British) took place on April 22, 1915, at 1700 GMT (18:00 CET) in the perimeter of the Langemarck village near Ypres, when the prevalent wind finally turned in the northerly direction. Seven previous attempts had to be aborted because of unfavorable wind. The attack released 150 tons of chlorine gas from 1600 big and 4130 small cylinders placed at a distance of about $1 \mathrm{~m}$ from each other, covering about $6 \mathrm{~km}$ of the front. The chlorine gas concentration achieved was about $0.5 \%$ at a distance of $50-100 \mathrm{~m}$ from the cylinders, see Fig. 3. The first attack not only threw the Allied forces into a panic but reportedly injured about 5000 and killed about 1000. In addition, the Germans were able to capture 60 guns and a large swath of territory. To no avail, however, as the German military was unprepared to take advantage of the breakthrough:

Unfortunately, the OHL had not prepared sufficient reserves because of doubts about the effectiveness of the new weapon. Otherwise it would have been possible to make a decisive advance (Lummitzsch 1955).

In spite of the "success" of the attack, it became clear that the predominant easterly winds made gas cloud attacks too unpredictable and unreliable a means upon which to base a new method of warfare. This led Haber to a renewed interest in poison gas grenades and shells, which were not so dependent upon rapidly changing meteorological conditions.

\section{The Indispensable Fritz Haber}

Fritz Haber, see Fig. 4, the founding director of the Kaiser Wilhelm Institute for Physical Chemistry and Electrochemistry, took part in the widespread enthusiasm that accompanied German mobilization and entry into the First World War in the 


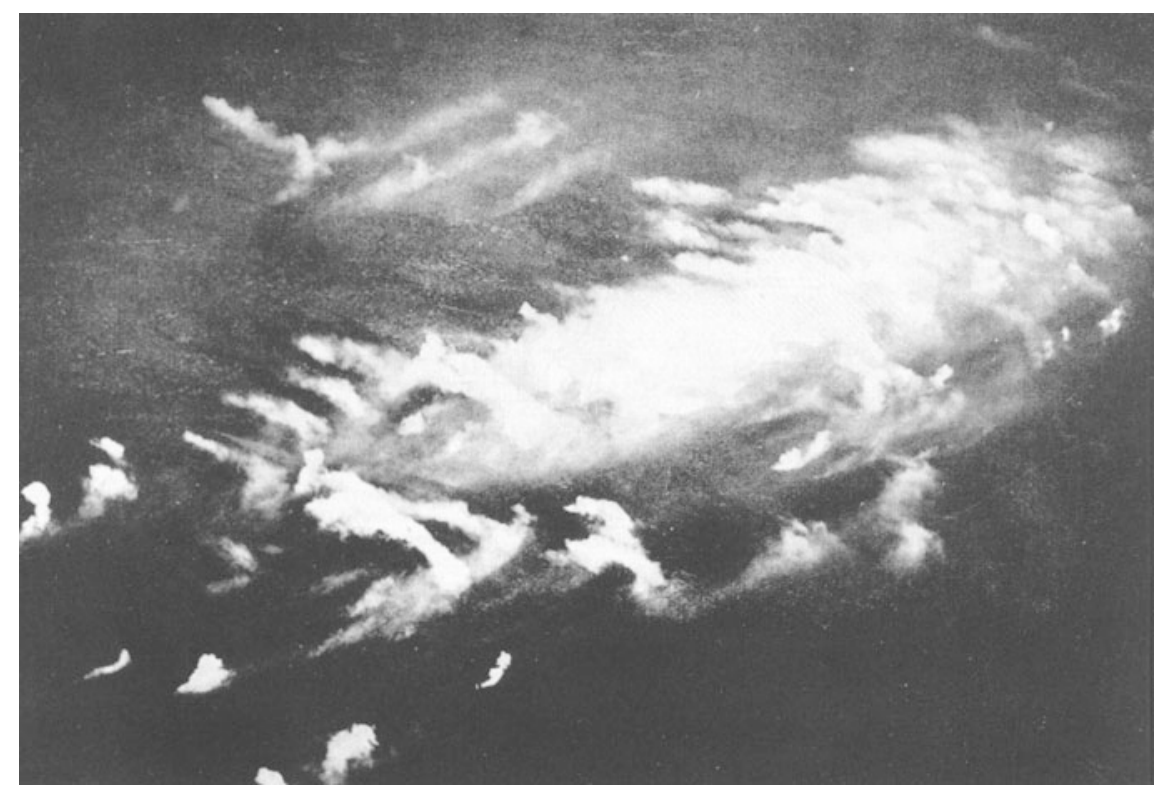

Fig. 3 Aerial view of the chlorine cloud released by the German troops on April 22, 1915 at Ypres. Photo: Martinetz 1996, VIII

summer of 1914 (Hoffmann 2014, 7-31) and registered for voluntary military service at the beginning of August. He gave voice to his euphoria in a letter to Svante Arrhenius in Stockholm, writing:

This is a war in which our entire people is taking part with full sympathy and its utmost abilities. Those who don't bear arms work for the war, and everyone scrambles forward voluntarily for the slightest accomplishment. You know Germany all too well not to know that such a unanimous commitment to a cause is only possible amongst us when all are conscious that the good of the nation must be defended through a just struggle. You should give no credence to the absurd fiction, according to which we are conducting a war out of military interests ... but we now see it as our ethical duty to take down our enemies with the use of all our strength and bring them to a peace that will make the return of such a war impossible for generations and give a solid foundation for the peaceful development of western Europe (Zott 1997, 77).

When Adolf von Harnack, as president of the Kaiser Wilhelm Society (KWG), called together all of the institute directors on August 12, 1914 to discuss possible consequences of the war for the work of the KWG, Haber was already occupied by military concerns and sent his deputy Gerhard Just, see Fig. 4, in his stead. Haber worked first as a scientific consultant in the Ministry of War for the Artillery Command and the Production Department, where his expertise in applied chemistry and ammonia synthesis were particularly valued. Representatives of German political establishment and industry had quickly realized that a limit on raw materials made a long war unsustainable for Germany. Nitrates were of particular 
concern, as Germany relied upon Chilean saltpeter to supply both its fertilizer needs and its production of explosives and propellants, but the British sea blockade threatened to cut off this source. The war would also lead to shortages of myriad other raw materials and create related bottlenecks in industrial production. Hence, German chemists faced the challenge of rationalizing use and production of these scarce materials or finding substitutes for them.

Haber not only followed his maxim "In peace for mankind, in war for the fatherland"3 personally, but applied it to his entire institute and promptly redirected its resources toward projects relevant to the war. The conversion to military research projects proceeded surprisingly smoothly and without noticeable resistance. This raises the question whether the war euphoria alone eased the transition or whether something inherent to the research policy of the Kaiser Wilhelm Society, especially its chemical institutes, enabled such a conversion. As Johnson has argued:

True to his nature, Fischer stamped the scientific program of the Kaiser Wilhelm Society with a dual character. On the one hand, it was aimed at the most fundamental problems of natural science; but on the other, it was intended to produce solutions to technological problems of the highest national interest, particularly with regard to providing domestically available synthetic or artificial substitutes for imported materials (Johnson 1990, 133).

The development of the catalytic process for ammonia synthesis was already one realization of the desire to manufacture domestic substitutes for key imported goods. It is also amongst the common tenets of the history of WWI that without the Haber-Bosch process, the German military would have run out of munitions in 1915. Similar intentions led Haber to his wartime partnership with the Raw Materials Department of the War Ministry under Walther Rathenau, which eventually led him to research chemical means for waging war. As Johnson pointedly summed up the progression: "the logic of Ersatz [substitute] led to the problems of munitions, and eventually to poison gas" (Johnson 1990, 133).

In the first months of the war, the Institute searched for ways to economize or provide substitutes for so-called "war materials"- substances required for the operation of firearms, artillery and other war machines; examples include toluene, glycerin and saltpeter. Gerhard Just made rapid progress in this field, in collaboration with Otto Sackur, see Fig. 4. Together they were able to demonstrate, through careful freezing and boiling point measurements, that a combination of xylene and certain water-soluble fractions of crude oil could replace toluene as an anti-freeze in engines. Their discovery meant a savings of roughly 400 tons of toluene per month that could then be used in the production of TNT and other explosives and munitions. In the autumn and winter of 1914, Haber and his colleagues also took part in the development of respiratory irritants and tear gases in connection with the already mentioned conservation efforts.

\footnotetext{
${ }^{3}$ Usually quoted in this abbreviated form. For a full quote in German, see Haber (1920). Haber was referring to the attitude of Archimedes.
} 

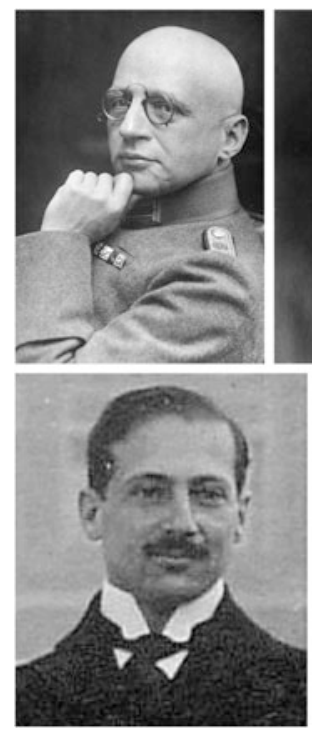
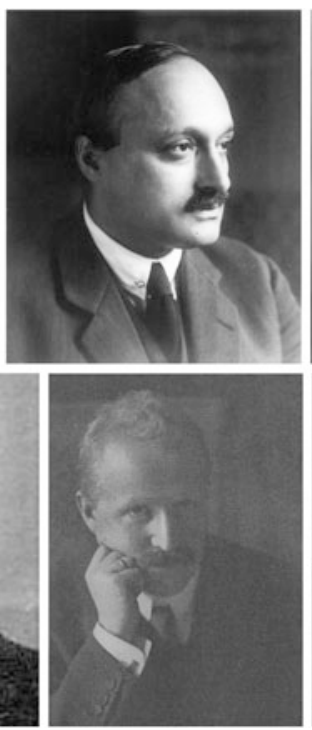
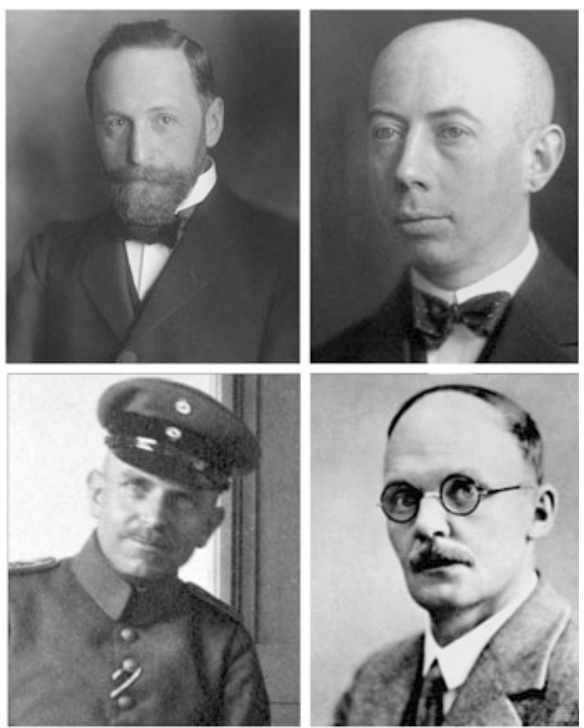

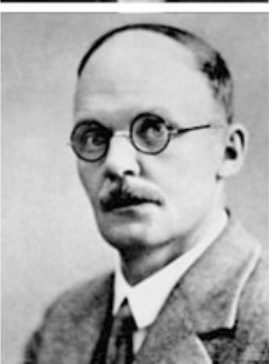

Fig. 4 Distinguished German scientists involved in chemical warfare. Clockwise from top left: Fritz Haber, James Franck, Richard Wilstätter, Gustav Hertz, Hans Geiger, Otto Hahn, Otto Sackur, and Gerhard Just. Photos: Archiv der Max-Planck-Gesellschaft, Berlin-Dahlem, Jahresbericht der Schlesischen Gesellschaft für Vaterländische Kultur 1915, 1: 35-37, private collections of the authors

In connection with their efforts to develop new and more effective explosives and propellants, Haber, Just and Sackur attempted to replace the irritant in the T-shells ${ }^{4}$ with a substance that would act as both irritant and propellant. Someone thought of using cacodyl chloride, which Robert Bunsen had first synthesized in 1837, but which chemists had scarcely researched since, because it was such a powerful irritant and explosive. On 17 December 1914, during an experiment intended to tame cacodyl chloride, there was an explosion in the laboratory. Sackur was fatally wounded, Just lost his right hand. Haber had left the room shortly before the blast and remained physically unharmed. Nevertheless, he was unsettled by the death of his highly-talented colleague and steadfastly honored his memory (James et al. 2011, 27).

After the accident, research on cacodyl chloride at the Institute was halted, but the explosion also marked a turning point not wholly ascribable to its tragic consequence: the end of significant research on explosives at the Institute and the beginnings of poison gas research. Sometime in the first half of 1915, Haber redirected research at his institute toward the needs of gas warfare. Unfortunately, the available sources do not provide precise answers as to when or how this occurred.

\footnotetext{
${ }^{4}$ Shells filled with T-Stoff.
} 
The men of the gas brigades who carried out the chlorine cloud attack at Ypres, amongst whom numbered many Dahlem and Berlin scientists, including James Franck, Otto Hahn, Gustav Hertz, and Hans Geiger, see Fig. 4, experienced an immediate improvement in status. Haber was even promoted by the Kaiser from the rank of staff sergeant to captain, ${ }^{5}$ a potent recognition of the value of his efforts. This advance in rank appears to have further motivated Haber to the self-assigned task of promoting chemical warfare, first as chemical advisor to the Ministry of War, then, beginning in November 1915, as head of the "Central Office for Chemical Concerns" in the Artillery Division. He essentially abandoned scholarly research and concentrated upon the problems of chemical warfare. In the words of his biographer Dietrich Stoltzenberg:

everything else in his life [faded] into the background. Wife and family now had almost no influence on his life. In fact, for him, family, friends, and acquaintances were just further sources of aid for his cause (Stoltzenberg 1994, 256).

\section{Haber's Kaiser Wilhelm Institute Under Military Command}

Like most academic institutes, Haber's was essentially abandoned with even Haber spending much of his time near the front directing preparations for gas attacks. Then, at the end of April 1915, the Supreme Army Command assigned Haber the task of developing defensive measures against gas attacks. Haber systematically redirected his institute toward the pursuit of this goal and built it up into a German center for gas warfare research. Over half of the expenditures of the Institute in 1915 were for military purposes, above all for "experiments on the development of gas warfare methods." As of February 1916, the Institute worked "almost exclusively" for the military, which covered all related costs, including standard operating expense; the Institute even took on an army administrator, Lieut. Alfred Glücksmann, amongst whose duties was managing the Institute's budget (Szöllösi-Janze 1998, 344).

As noted, the first task of Haber's institute was the exploration of defensive measures and the development of gas masks. To this end, a special department for "Chemistry of Gas Defense" was established under Hans Pick. Among the duties of this department was the development and testing of gas mask prototypes, in collaboration with production firms. At the conclusion of these tests, the preferred design was one proposed by Leopold Koppel's Auergesellschaft, which would produce the masks in great numbers. ${ }^{6}$ Still, mask design was only one part of

\footnotetext{
${ }^{5}$ Non-Jewish members of the German professoriate typically received the rank of a major, Szöllösi-Janze (1998, 63-64, 267); Schmaltz (2014, 206).

${ }^{6}$ Leopold Koppel, a banker and enterpreneur, funded Haber's KWI.
} 
effective gas defense; yet more important was the development of effective filters. Early in 1915 filter designers had to reckon with chlorine and phosgene attacks, but as new and ever more malicious poisons were introduced, including mixtures of compounds consciously designed to penetrate the masks, the filters needed to be continuously updated and retested. Responsibility for filter development initially fell to the neighboring KWI for Chemistry, in the person of Haber's colleague and friend Richard Willstätter, see Fig. 4. The first complete new gas masks, body and filter, were delivered to the troops in September 1915, and by the end of January 1916, the entire Western Front was equipped with masks, an enormous technical as well as logistical accomplishment. ${ }^{7}$

The initial fabrication of gas masks also marked the beginning of an unprecedented expansion of the Institute, which took place between the autumn of 1915 and the end of 1917. The Institute grew to include 10 departments and employ 1500 scientists and support staff, the latter composed overwhelmingly of women, see Fig. 5, all employed in the research, development and testing of gas warfare equipment. This number would rise to 2000 at the end of the war (Szöllösi-Janze 1998, 348). The expansion began with the departments of Reginald Herzog and Hans Pick, see Fig. 6 and Table 1. Herzog and his coworkers took over the supervision and testing of gas mask production, while Pick dedicated himself to the chemical aspects of gas defense. Then, in November 1915, Friedrich Kerschbaum, see Fig. 6 and Table 1, previously technical adjutant to Haber, established a department devoted to the study of enemy poisons and defensive measures, as well as the development of new poisons. The founding of this department and the near simultaneous appointment of Haber to head the Central Office for Chemical Concerns were the final, decisive steps in the commissioning of the KWI for Physical Chemistry and Electrochemistry for poison gas research by the military. The subsequent unprecedented expansion of the Institute would make it a prototypical example of "big science," not only with respect to its sheer size but also, and above all, with respect to the complexity and interdisciplinarity of its organizational structure and research methods (cf. Szöllösi-Janze and Trischler 1990). The institute also served as an early example of how quickly and smoothly resources for the establishment of optimal research conditions can be secured in a military or security context whereas, under normal circumstances, their attainment frequently involves near-endless, often unsuccessful struggle. As Johnson put it, "the Dahlem complex gradually assumed the character of a research center for tactical military science and technology" (Johnson 1990, 189). Or, looking forward with the words of Fritz Stern, the Haber Institute during the First World War became "a kind of forerunner of the Manhattan Project" (Stern 1999, 119). ${ }^{8}$

\footnotetext{
${ }^{7}$ We note that the testing of the gas masks was done, among others, by James Franck, Otto Hahn, and other scientists who let themselves be personally exposed to chemical warfare agents such as phosgen in the test chambers at Haber's KWI (Szöllösi-Janze 1998, 347-348).

${ }^{8}$ However, the Manhattan Project was by about two orders of magnitude larger in terms of human resources alone. See Manhattan District History Book I-General, Vol. 8-Personnel, dated 19 February 1946.
} 
Similarly striking expansions of chemical warfare research occurred in the other warring nations, further encouraging German efforts. Although there was initially significant political debate in Britain as to whether German use of chemical weapons justified retaliation in kind, by May 1915 the British Ministry of Munitions had formed a chemical subcommittee, and in March 1916 the British opened a chemical weapons testing facility at Porton Down. France saw no similar political debate and had, in fact, already employed grenades filled with lethal chemicals early in the war, see below. In June 1915, France established a Directorship of Chemical War Materials under the Ministry of War and centralized chemical warfare research in laboratories near Paris (Lepick 1998). In so far as German efforts were exceptional, it was primarily in the degree to which research remained concentrated at the KWI for Physical Chemistry and Electrochemistry (Haber 1986; Martinetz 1996).

By October 1916, there were five departments dedicated to gas warfare research. ${ }^{9}$ In addition to those already mentioned, Herbert Freundlich, see Fig. 6 and Table 1, headed a department dedicated to the supervision and testing of mask filters. That autumn, roughly one year into its expansion, the Institute employed a scientific staff of 77 chemists, pharmacists, and engineers, as well as a support staff numbering over 100. Up to that point, the Institute officially remained under the auspices of the Kaiser Wilhelm Society and the Koppel Foundation, which lodged muted complaints against the redirection of the Institute.

At the beginning of 1917, Haber's Office for Chemical Concerns was detached from the Artillery Division and refashioned into an independent department of the General Staff, Department A10, cf. Fig. 1. This department was then assigned control of Haber's institute, bringing the KWI for Physical Chemistry and Electrochemistry under military command. This reorganization was the result of a motion by the Ministry of War summarized by Haber in his letter to the minister of education that

\begin{abstract}
the whole operation of the institute be converted to a military one while keeping the name "KWI for Physical Chemistry and Electrochemistry" and that the staff currently working at the institute should be [...] put on the staff of the military administration. The Ministry of War would $[\ldots]$ as supervising authority still control the general direction of the institute on the condition that the position of Privy Counselor Capt. Haber [...] as scientific director of the institute would remain unchanged, as would the positions of the others who had been members of the staff in peace time. ${ }^{10}$
\end{abstract}

This administrative move was accompanied by further enlargement of the Institute, primarily related to the intensification of efforts to develop new poisons. According to a report from Haber in September 1917, it was at this point that the Institute came to employ a staff of approximately 1500 , with roughly 150 scientists and engineers, divided into 10 departments. Prominent scientific members included later Nobel laureate Heinrich Wieland, see Fig. 6 and Table 1, who worked on the production of new toxic gases, including the blistering agent mustard gas (LoSt,

\footnotetext{
${ }^{9}$ We draw on James $(2011,25-34)$.

${ }^{10}$ Fritz Haber, Letter to the Ministry of Education from 31 January 1916, Stoltzenberg (2004, 139).
} 


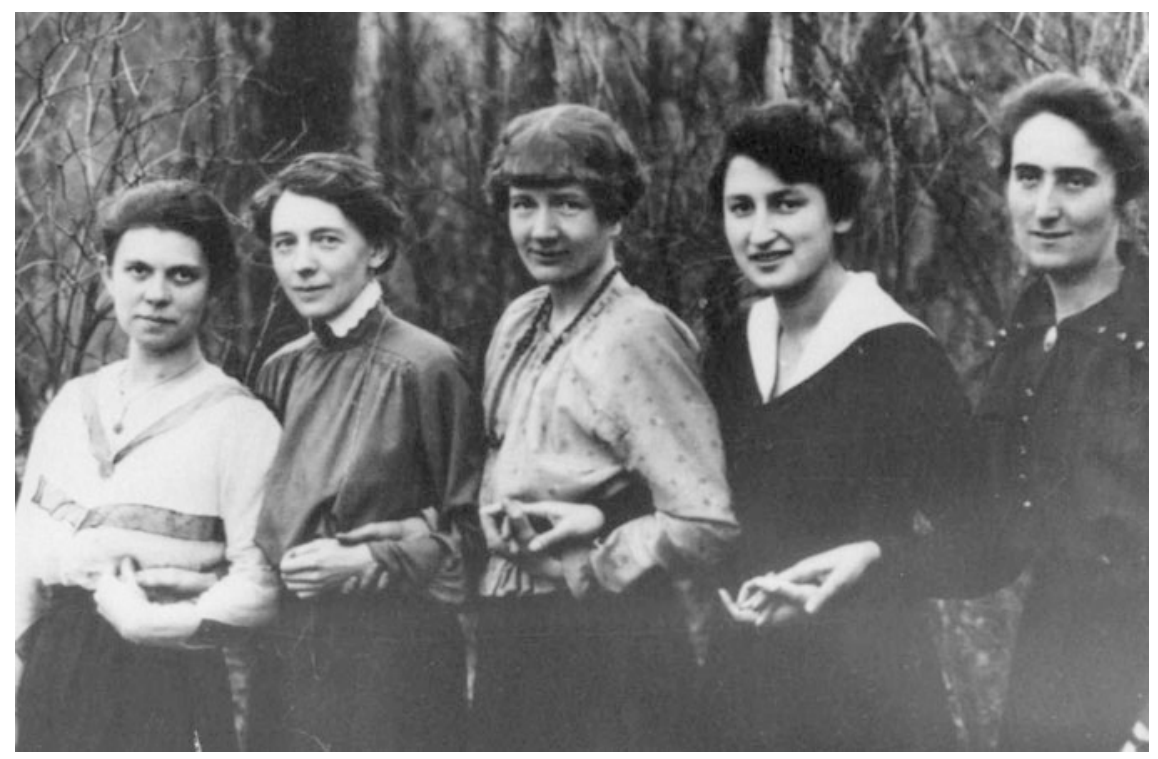

Fig. 5 Out of the 1,500 employees of Haber's KWI after it became the German center of chemical warfare research and coordination, the majority were women. Photo: Archiv der Max-Planck-Gesellschaft, Berlin-Dahlem

named for Haber's coworkers Lommel and Steinkopf and also known as Yperite) and Ferdinand Flury, see Fig. 6 and Table 1, who tested newly-developed gases on live animals. Heinrich Wieland, who would receive the 1927 Chemistry Nobel Prize "for his investigations of the constitution of the bile acids and related substances," initiated his research into the relationship between steroids and the bile acids in 1912. During his 1917-1918 military service at Haber's Institute, for which he may have qualified due to his pre-war work on the fulminic acid, a primary explosive whose vapors are highly toxic, Wieland synthesized adamsite, in addition to his involvement in the synthesis of mustard gas. Wieland's penetration into the structure of the polymeric fulminic acids helped to lift the veil over what he called "an arid structural desert" under which he later discovered the constitution of bile acids as well (Karrer 1958, 342). To what extent Wieland was able to advance the line of research on steroids during his service at Haber's Institute remains unclear.

The two original Institute buildings could not contain all of the new departments and coworkers, and ever more barracks, kennels and other outbuildings sprang up on the Institute grounds, see Fig. 7. When even this space was consumed, rooms were requisitioned from the neighboring KWIs for Chemistry and for Biology, with the consent of their respective directors. ${ }^{11}$ Toward the end of 1916, further growth

\footnotetext{
${ }^{11}$ And perhaps sometimes even without it. As Lise Meitner from the adjacent KWI for Chemistry noted: "Haber's people treated us like conquered territory; they didn't take what they needed but what they liked." (Stoltzenberg 1994, 255).
} 

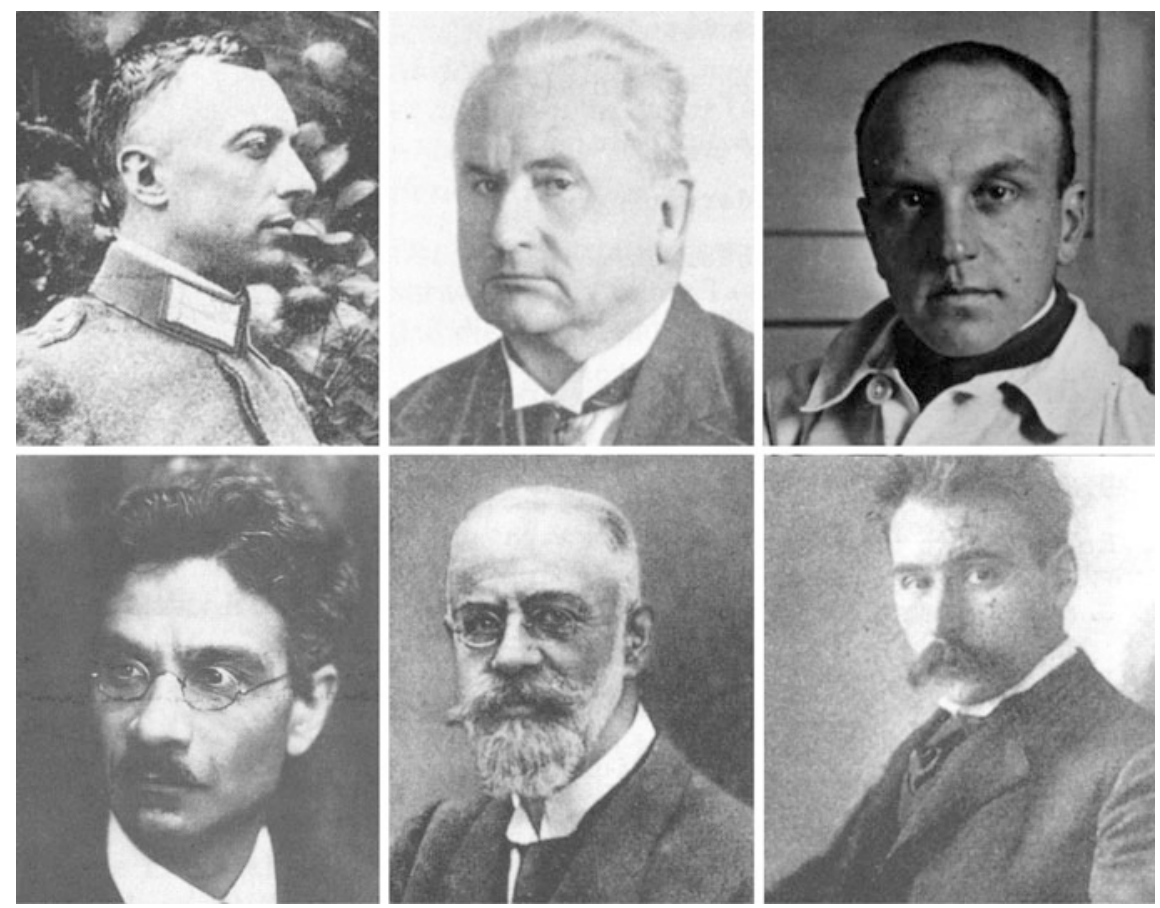

Fig. 6 Prominent heads of chemical warfare departments at Haber's KWI for Physical Chemistry and Electrochemistry when the institute was under military command. Clockwise from top left: Friedrich Kerschbaum, Ferdinand Flury, Heinrich Wieland, Reginald Oliver Herzog, Paul Friedländer, and Herbert Freundlich. Photos: Archiv der Max-Planck-Gesellschaft, Berlin-Dahlem and Martinetz 1996, II

Table 1 Departmental structure of Haber's KWI at the end of World War I, according to the 1921 "Hartley Report." The "defensive" departments are marked in red, the rest are the "offensive" departments (Haber 1986, 127)

\begin{tabular}{|c|c|c|}
\hline Department & Assignment & Head \\
\hline A & Development of respirators; Supervision of gas mask production & Reginald Oliver Herzog \\
\hline B & $\begin{array}{l}\text { Development of chemical weapons; Testing of enemy chemical } \\
\text { weapons and protective gear }\end{array}$ & Friedrich Kerschbaum \\
\hline C & Development of respirator drums and other protective appliances & Ludwig Hans Pick \\
\hline $\mathrm{D}$ & Synthesis of new chemical warfare agents & Heinrich Wieland \\
\hline $\mathrm{E}$ & Pharmacology and toxicology; Testing on animals & Ferdinand Flury \\
\hline F & Supervision of the production of respirator drums & Herbert Freundlich \\
\hline G & Supervision of the production of shells and fuses for gas munitions & Wilhelm Steinkopf \\
\hline H & Trench mortars; Explosives & Otto Poppenberg \\
\hline J & Supervision of the production of chemical warfare agents & Paul Friedlănder \\
\hline $\mathrm{K}$ & Particulate clouds - development of the "Gasbuchse" & Erich Regener \\
\hline
\end{tabular}


occasioned moves even further afield, and the Institute rented space in the Pharmaceutical Institute of the University, in a weaving school on Warschauer Platz, in the State Offices in Steglitz and on Königin-Luise-Straße in Dahlem (James et al. 2011, 32).

Compared to the extent of the research carried out on poison gases, the original documentation that remains is truly sparse. A single, relatively complete research report on chlorarsines remains from Johannes Jaenicke, at the time a member of Hans Pick's Department C, along with scattered reports from toxicity tests on animals and volunteers from the Institute staff (Haber 1986, 109). Extant correspondence between the main researchers is similarly sparse.

The post-war Allied forces reports on the Institute are somewhat more informative concerning the conduct of poison gas research, but even they are disappointingly superficial when it comes to questions of research procedures and practices, aside from quality testing protocols. Nevertheless, from these limited sources, the principal of them being the Hartley Report and its rendition in the book by Fritz Haber's son Ludwig (Lutz) Haber, ${ }^{12}$ it is possible to sketch the following outline of chemical weapons research at Haber's institute.

The ongoing development of gas masks and filters, in increasingly close cooperation with industry, took place in Departments A (Herzog) and C (Pick). The work of these departments relied upon a steady exchange of knowledge between laboratory researchers and battlefield informants. Later in the war, prototypes from these departments would be tested against new poisons from Department B (Kerschbaum) (Hartley 1925, 39-42). Members of Kerschbaum's department strove to find and identify substances with potential for use in gas cloud and shell attacks. Their work consisted of a mixture of literature research to identify substances with an optimal combination of noxiousness, low boiling point and high vapor pressure, and experiments on animals and volunteers from the Institute staff to confirm the irritating or toxic effects of these substances (Hartley 1925, 45). Also, Kerschbaum along with Haber supervised the poison-gas production and filling facility ("Gasplatz") at Breloh, see Fig. 8. Department D (Wieland) focused specifically on deleterious arsenic and sulfur compounds, for instance mustard gas, and performed primarily laboratory research, including attempts to synthesize new substances with effects analogous to known poisons and irritants. Research on the physiological effects of various poisons, including careful study of their relative toxicity, occurred in Department E (Flury) and relied upon extensive animal experimentation. It was also Flury and his collaborators who promoted use of the so-called "Haber Constant," the product of the concentration and the exposure time required to cause death. This constant aided early efforts to define limits on

\footnotetext{
${ }^{12}$ Lutz Haber's personal interest in the topic of chemical warfare was fueled not just by his family lineage but also by his acquaintance and friendship with Harold Hartley, whose confidant - and in a sense heir of his extensive collection of materials connected with chemical warfare in WWILutz Haber had become. Sir Harold Hartley was Fritz Haber's counterpart at the British War Office during WWI who, after the war, was in charge of inspecting German research and production facilities related to chemical warfare, and banned by the Versailles Treaty.
} 


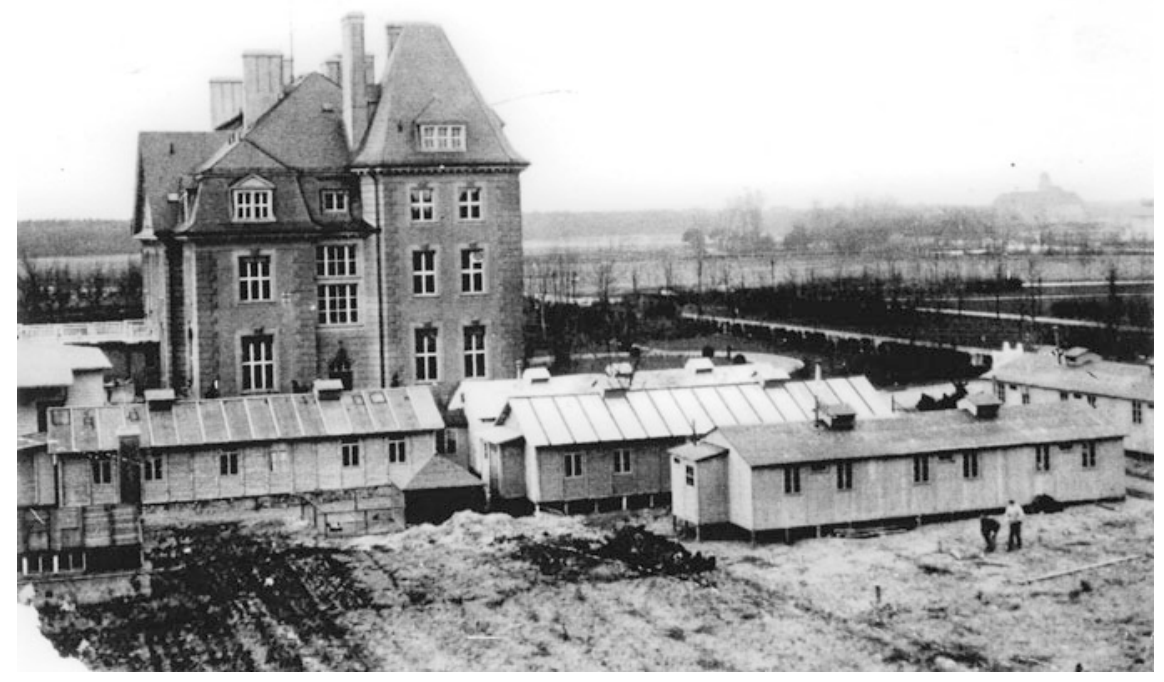

Fig. 7 Haber's KWI for Physical Chemistry and Electrochemistry with surrounding barracks, circa 1917. Photo: Archiv der Max Planck Gesellschaft

hazardous substances in the civilian sphere. Department $\mathbf{J}$ (Friedländer) was responsible for testing the quality of chemical weapons produced by industry, for which it employed predominantly classical analytical methods rather than measurements of physical constants (Hartley 1925, 50-52). Only in Department K, under Erich Regener, did techniques from physical chemistry play a central role. Regener's group used ultramicroscopes to study the small particles that constitute powders and smokes and their ability to penetrate existing gas mask filters.

Post-war assessments of the scientific value of this research by Allied representatives and later historians have been almost universally negative. In his own remarks on the subject during the 1920s, Haber emphasized the effectiveness and humaneness of chemical weapons, but, nonetheless, explained to Allied agents that all of the important toxic substances used in the war had already been synthesized and studied before 1914 and that "no systematic progress had been made" in their research. In the same vein, Richard Willstätter reported to the Allies that he did not consider the synthesis research pursued at Haber's institute particularly serious.

Apart from developing additional chemical agents at his Kaiser Wilhelm Institute (such as phosgene and mustard gas), Haber introduced the procedure of "Bunteschiessen" (variegated shelling), which consisted of first deploying "Maskenbrecher"-irritants based on organic arsenides (called Clark I and II) that penetrated all available filters and forced those under attack to remove their gas masks - and subsequently shelling with poisons such as phosgene or mustard gas (Haber 1986, 114-116). 


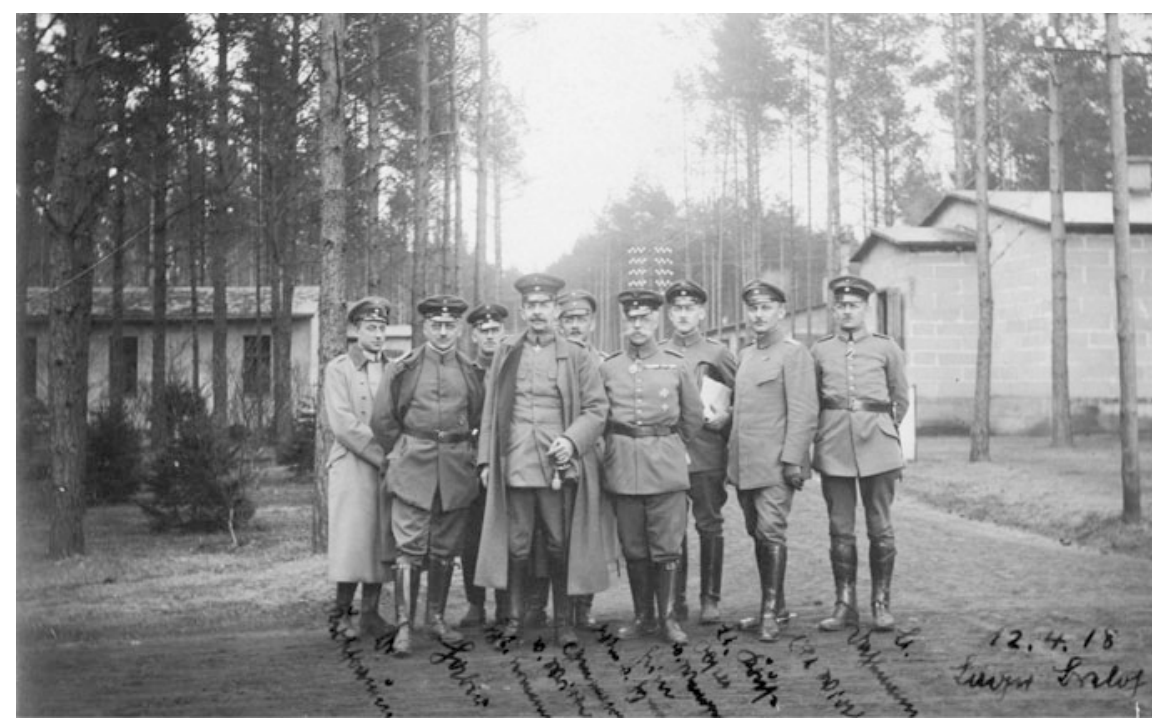

Fig. 8 Inspection of the gas-testing and storage facility in Breloh near Münster on April 12, 1918. Head of the General War Department A (Allgemeines Kriegsdepartment A), Col. Ernst von Wrisberg (4th from left); Commander of the Breloh facility, Lieutenant-Colonel Ernst von Wangenheim (4th from right); Commander of the Field-Munitions Institute, Capt. Dr. Ludwig Hermann (3rd from left); Head of Department B at Haber's Institute, Dr. Friedrich Kerschbaum (1st from left). Capt. Fritz Haber (2nd from left). Photo: Archiv der Max Planck Gesellschaft

\section{Haber's Views on Chemical Warfare}

Haber advertised the first use of a chemical weapon as an important milestone in the "art of war" - and saw its psychological effect as key:

All modern weapons, although seemingly aimed at causing the death of the adversary, in reality owe their success to the vigor with which they temporarily shatter the adversary's psychological strength (Haber 1924, 36):

Haber also pointed out that key to success in chemical warfare are "intellectual imponderables" of the troops.

A strict selection separates the troops that are capable of maintaining gas-discipline and who fulfill their combat task from the martially inferior mass of those who crumble and abandon their posts (ibid., 39).

He also emphasized that the variability of the effects of chemical weapons presents ever new demands on the "moral resistance" of the troops, as opposed to artillery shelling that is always the same and people get eventually used to it (ibid., 37).

Thus Haber viewed chemical weapons as a strategic means to break the stalemate of trench warfare by forcing the adversary to surrender, shorten the war, and 
thereby preclude the slaughter of millions by artillery and machine gun fire. In this sense he also referred to chemical weapons as "humane." He was not alone to do so, see below.

Haber's enthusiasm for chemical weapons had an important caveat, described by Haber's biographer Margit Szöllösi-Janze in this way:

Was [Haber] a fanatic of gas-warfare? One must not overlook that he saw the significance of the gas weapon in its stupefying character and assessed the inherent dynamics of its use differently than the military. In his opinion chemical weapons could be effective and lead to a shortening of the war only if the war came to an end before the adversary would be able to develop suitable protective measures and even more dangerous chemical agents. For this reason, [Haber] voiced his opposition at a meeting in 1917 with [General Erich] Ludendorff [deputy of von Falkenhayn's successor as Chief of OHL, Paul von Hindenburg] to the use of mustard gas [that represented an escalation of the chemical war], which struck him sensible only if Germany could take advantage of its head start and win the war within a year (Szöllösi-Janze 1998, 332).

And indeed, the French began production of mustard gas in July 1918. Here's how Harold Hartley described the path of the Allies to mustard gas:

[Hartley] was awakened early on that 13 July [1917] and was informed that the Germans had fired a new type of shell [at Ypres] that made a "plop"-like sound when it burst [...] The next day [Hartley] had located some unexploded shells with yellow cross markings. They were defused, taken to [the General Headquarters], opened, the contents analyzed [...] and the findings compared with the entry in Beilstein. By 16 July [the British] knew what the stuff was, and later analyses added little to this knowledge (Haber 1986, 192).

Haber's correspondence reveals his fascination with the new tactical possibilities opened by gas warfare and the room for "scientific imagination" that such technological means for conducting war had offered (Szöllösi-Janze 1998, 327). He used (and perhaps coined) the metaphor that conventional warfare was like playing checkers whereas warfare enhanced by chemical weapons was like playing chess. Haber never regretted his involvement in chemical warfare.

As for legal issues with chemical warfare, Haber put the blame for any transgressions against international law squarely on Erich von Falkenhayn. He did so in a testimony - which took the form of lectures - delivered to an investigative committee of the Reichstag in 1920-1923. However, in this testimony, Haber did not shy away from playing a legalistic shell game when he argued that German gas attacks were carried out either without the use of shells (like the chlorine cloud attacks) or with shells loaded, in addition to poison gas, with explosives (whereas the Hague conventions prohibited the use of shells or grenades filled solely with poisonous substances).

Haber also correctly claimed that chemical weapons were first used in WWI by the French - already in August 1914 — when they fired rifle grenades filled with the highly toxic ethyl bromoacetate. Although ineffective because of the low concentrations achieved, the intended purpose was, according to Fritz Haber, the same as that of the German chlorine cloud: to force the enemy out of his trench positions by exposing him to an asphyxiating agent (Haber 1924, 87). This view was validated by the German parliamentary committee, which concluded: 
Neither the German nor the French governments, nor as far as is known, any other power participating in the war or a neutral one raised any objections against the modes of action in the gas war. From this it can be concluded that both sides viewed the Hague Conventions of 29 July 1899 and 18 October 1907 as obsolete and by silent agreement regarded them as annulled. Even when accepting this assumption, it remains a fact that the first obvious transgression of an international agreement was on the French side, whereas Germany only followed and thereby merely took a countermeasure as accepted in international law (Stoltzenberg 1994, 152).

\title{
6 The Legacy of Ypres
}

The universal abhorrence of chemical weapons as manifestly inhumane is surprisingly recent and so is their classification as weapons of mass destruction. While the latter is a concept of the nuclear age, the former is not... At the time of their use in the First World War, the perverse-sounding notion that chemical weapons were in fact humane had been a part of the vocabulary of munitions and war experts of the Central Powers and the Entente alike, including, for instance, that of the U.S. Assistant Secretary of War and Director of Munitions, Benedict Crowell:

\begin{abstract}
The methods of manufacturing toxic gases, the use of such gases, and the tactics connected with their use were new developments of this war; yet during the year 1918 from 20 to 30 per cent of all American battle casualties were due to gas, showing that toxic gas is one of the most powerful implements of war. The records show, however, that when armies were supplied with masks and other defensive appliances, only about 3 or 4 per cent of the gas casualties were fatal. This indicates that gas can be made not only one of the most effective implements of war, but one of the most humane (Crowell 1919, 396).
\end{abstract}

The few who forewarned Haber and the German military leadership that the German use of chemical weapons would lead to a quick retaliation by the Entente powers and a widespread use of chemical weapons were ignored. And indeed, the Entente introduced its own potent chemical arsenal within a few months of the first German chlorine cloud attack at Ypres, see also Table 2.

Table 2 Production of chemical weapons by country, in metric tons (Martinetz 1996, 120)

\begin{tabular}{|l|r|r|c|r|r|r|r|r|}
\hline Country & Chlorine & Phosgen & \multicolumn{1}{c}{$\begin{array}{c}\text { Di- } \\
\text { phosgen }\end{array}$} & \multicolumn{1}{c}{$\begin{array}{c}\text { Mustard } \\
\text { gas }\end{array}$} & \multicolumn{1}{c}{$\begin{array}{c}\text { Chlor- } \\
\text { picrin }\end{array}$} & \multicolumn{1}{l}{ HCN } & Total \\
\hline Germany & 58,100 & 18,100 & 11,600 & 7,600 & 4,100 & - & 99,500 \\
\hline Britain & 20,800 & 1,400 & - & 500 & 8,000 & 400 & 31,100 \\
\hline France & 12,500 & 15,700 & - & 2,000 & 500 & 7,700 & 38,400 \\
\hline U.S.A. & 2,400 & 1,400 & - & 900 & 2,500 & - & 7,200 \\
\hline Total & 93,800 & 36,600 & 11,600 & 11,000 & 15,100 & 8,100 & 176,200 \\
\hline
\end{tabular}


Artillery shells filled with chemical agents grew from a negligible proportion in 1915 to about $50 \%$ of the German, $35 \%$ of the French, $25 \%$ of the British, and $20 \%$ of the American ammunition expenditure by the Armistice (Spiers 2016). Providing little advantage to either of the equally equipped belligerents, chemical weapons greatly increased the already unspeakable suffering of the troops on both sides of both the Western and Eastern fronts. The British historian Edward Spiers recently characterized the WWI chemical weapons as "weapons of harassment" (ibid.). According to Augustin Prentiss's count (Prentiss 1937, 649), a total of about 90,000 soldiers were killed and 1.3 million injured by chemical weapons in WWI. What put finally an end to the war was the economic collapse of Germany (Mommsen 2011).

Albert Einstein's pacifist view contrasted sharply with that of his friend Haber. As he would put it later: "Warfare cannot be humanized. It can only be abolished" (Rowe and Schulmann 2007, 224). Strangely enough, there is no record of Einstein's criticism of Haber's WWI efforts, although Einstein occupied an office at Haber's institute at the time and must have been aware of what was going on. Gruesome as they were, chemical weapons have been banned only since 1997 (Organisation for the Prohibition of Chemical Weapons). Much of the military death toll in WWI (estimated to be at least 10 million troops) was, however, due to high explosives produced by the chemical industries of the warring nations. Hence the characterization of WWI as the "chemists' war," although chemical warfare surely added much weight to it. We note that the development and acquisition of the Haber-Bosch technology by Germany just in time for the Great War was key to sustaining her war effort: without it, the embargoed supplies of Chilean saltpeter would have run out within months and WWI would have indeed been as brief as anticipated by the German military planners, except that it would have ended not in Germany's speedy victory but rather her abrupt defeat.

Haber was without question the driving force behind the centrally-directed development of chemical warfare in Germany, whose use during WWI violated international law and elicited both immediate and enduring moral criticism, and has thereby inadvertently come to personify the moral flexibility of scientific research (Stern 2011; Dunikowska and Turko 2011). His efforts during WWI illustrate how quickly the fine line between the tolerable and the unacceptable can be crossed, in this case with fatal consequences.

As Haber's biographer Dietrich Stoltzenberg aptly noted: "It is easy to condemn [Haber]; it is much harder to make a sound judgment on him" (Stoltzenberg 1994, $153)$.

Acknowledgements We thank Dieter Hoffmann and Thomas Steinhauser (both Max Planck Institute for the History of Science) for most helpful discussions concerning chemical warfare research at Haber's institute and Robert Nye (Oregon State University) for his feedback on the manuscript. 


\section{References}

Crowell, Benedict. 1919. America's munitions 1917-1918: Report of Benedict Crowell, the Assistant Secretary of War, Director of Munitions. Washington: Government Printing Office.

Dunikowska, Magda, and Ludwik Turko. 2011. Fritz Haber: The damned scientist. Angewandte Chemie International Edition 50: 10050-10062.

Haber, Fritz. 1920. Die chemische Industrie und der Krieg. Die chemische Industrie 43: 350-352.

Haber, Fritz. 1924. Fünf Vorträge aus den Jahren 1920-1923. Berlin: Springer.

Haber, Lutz F. 1986. The poisonous cloud. Chemical warfare in the First World War. Oxford: Clarendon Press.

Hartley, Harold. 1925. Report on the German chemical warfare organization and policy, 19151918 (PRO/WO/33/1072).

Hoffmann, Dieter. 2014. ... im Frieden der Menschheit, im Kriege dem Vaterland. Universität und Wissenschaft im Ersten Weltkrieg. In Die Berliner Universität im Ersten Weltkrieg, ed. Gabriele Metzger. Berlin: H. Henemann.

James, Jeremiah, Thomas Steinhauser, Dieter Hoffmann, and Bretislav Friedrich. 2011. One Hundred Years at the Intersection of Chemistry and Physics. The Fritz Haber Institute of the Max Planck Society 1911-2011. Berlin: De Gruyter.

Johnson, Jeffrey. 1990. The Kaiser's Chemists. Science and Modernization in Imperial Germany. Chapel Hill, NC: UNC Press.

Karrer, Paul. 1958. Heinrich Wieland 1877-1957. Biographical Memoirs of Fellows of the Royal Society 4: 340-352.

Lepick, Olivier. 1998. La Grande Guerre Chimique, 1914-1918. Paris: Presses Universitaires de France.

Lummitzsch, Otto. 1955. Erinnerungen. Haber Collection Va Rep. 5, 1480, Archiv der Max Planck Gesellschaft.

Martinetz, Dieter. 1996. Der Gaskrieg 1914/18. Entwicklung, Herstellung und Einsatz chemischer Kampfstoffe. Das Zusammenwirken von militärischer Führung, Wissenschaft und Industrie. Bad Neuenahr-Ahrweiler: Bernhard \& Graefe Verlag.

Mommsen, Wolfgang. 2011. Die Urkatastrophe Deutschlands. Der Erste Weltkrieg 1914-1918. Stuttgart: Klett-Cotta.

Organisation for the Prohibition of Chemical Weapons. Chemical Weapons Convention. https:// www.opcw.org/chemical-weapons-convention. Accessed 27 Sept 2016.

Prentiss, Augustin. 1937. Chemicals in War: A treatise on chemical warfare. New York, NY: McGraw-Hill.

Rowe, David E., and Robert Schulmann. 2007. Einstein on politics. Princeton, NJ: Princeton University Press.

Schmaltz, Florian. 2014. Chemie als Waffe: Fritz Haber und Richard Willstätter im Ersten Weltkrieg. In Krieg! Juden zwischen den Fronten 1914-1918, eds. U. Heikaus and J. B. Köhne (eds.). Berlin: Hentrich \& Hentrich.

Spiers, Edward. 2016. The Gas War, 1915-1918: If not a war-winner, hardly a failure. In One Hundred Years of Chemical Warfare: Research, Deployment, Consequences, ed. B. Friedrich, D. Hoffmann, F. Schmaltz, J. Renn, and M. Wolf. Heidelberg: Springer.

Stern, Fritz. 1999. Einstein's German world. Princeton, NJ: Princeton University Press.

Stern, Fritz. 2011. Fritz Haber: Flawed greatness of person and country. Angewandte Chemie Inetrnational Edition 51: 50-56.

Stoltzenberg, Dietrich. 1994. Fritz Haber-Chemiker, Nobelpreisträger, Deutscher, Jude. Weinheim: Wiley-VCH.

Stoltzenberg, Dietrich. 2004. Fritz Haber. Chemist, Nobel Laureate, German, Jew. Philadelphia, PA: Chemical Heritage Press.

Szöllösi-Janze, Margit. 1998. Fritz Haber 1868-1934. Eine Biographie. München: C.H. Beck.

Szöllösi-Janze, Margit, and Helmuth Trischler (eds.). 1990. Großforschung in Deutschland. Frankfurt am Main: Campus. 
Deimling, von Berthold. 1930. Aus der alten in die neue Zeit. Ullstein: Lebenserinnerungen. Berlin.

Zott, Regine (ed.). 1997. Fritz Haber in seiner Korrespondenz mit Wilhelm Ostwald sowie in Briefen an Svante Arrhenius. Berlin: ERS-Verlag.

\section{Additional Open Access Information}

Section 6. The Legacy of Ypres reproduced with permission from Wiley-VCH Verlag GmbH \& Co. KGaA. This material has been published in Bretislav Friedrich, Angewandte Chemie International Edition (2013) 52: 2-3. CWiley-VCH Verlag GmbH \& Co. KGaA.

This material is subject to copyright protection and not covered by the Creative Commons Attribution Noncommercial License.

Open Access This chapter is licensed under the terms of the Creative Commons Attribution-NonCommercial 2.5 International License (http://creativecommons.org/licenses/by-nc/ $2.5 /$ ), which permits any noncommercial use, sharing, adaptation, distribution and reproduction in any medium or format, as long as you give appropriate credit to the original author(s) and the source, provide a link to the Creative Commons license and indicate if changes were made.

The images or other third party material in this chapter are included in the chapter's Creative Commons license, unless indicated otherwise in a credit line to the material. If material is not included in the chapter's Creative Commons license and your intended use is not permitted by statutory regulation or exceeds the permitted use, you will need to obtain permission directly from the copyright holder.

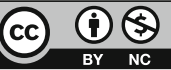

